\title{
ARAPSKA LINGVISTIKA I TEFSIR
}

\section{Sažetak}

Dobro poznavanje arapskog jezika i arapske lingvistike je temelj tefsira, ispravnog $i$ validnog tumačenja Kur'ana. Bez poznavanja arapskog jezika i njegovih disciplina, nije moguće pravilno razumijeti Kur'an. Zbog toga, islamski učenjaci naglašavaju da bavljenje tefsirom nije dozvoljeno bez poznavanja arapske lingvistike, s obzirom $d a$, ukoliko bi se to dopustilo, širom bi se otvorila vrata krivom interpretiranju Kur'ana, koji je glavni izvor islama.

Poznavanje arapskog jezika $i$ disciplina arapske jezikoslovne znanosti je jedna od osnovnih pretpostavki za bavljenje tefsirom. Nije dozvoljeno, niti je moguće, baviti se komentarisanjem Kur'ana ako komentator (mufessir) ne zna arapski - jezik na kojem je Kur'an objavljen. To podrazumijeva $i$ poznavanje disciplina obuhvaćenih arapskom jezikoslovnom naukom, kao što su etimologija, sintaksa, gramatika, poetika, stilistika $i d r$. Upuštanje u komentarisanje Kur'ana bez ispunjenja navedenih zahtjeva veoma je štetno, jer vodi $u$ pogrešno $i$ iskrivljeno tumačenje Allahove Knjige, a to znači u preinačavanje Allahovih, dž.š., poruka objavljenih u Kur'anu, što kao posljedicu može imati krivovjerstvo, nevjerovanje $i$ otpadništvo od islama.

$U$ ovom radu razmatra se značaj arapske lingvistike $u$ ispravnom tumačenju i interpretiranju Kur'ana časnog. Navedeni su brojni primjeri koji to ilustruju iz klasičnih tefsiriskih djela, naročito iz djela Ahkamu-l-Kur'an (Propisi Kur'ana), čiji je autor istaknuti učenjak hanefijske pravne škole Ebu Bekr er-Razi el-Džessas.

Ključne riječi: tefsir, arapska jezikoslovna znanost, lingvistika, stilistika, metafora, pravi smisao, aluzija, konciznost, El-Džessas, Ahkamu-l-Kur'an.

${ }^{1}$ Profesor tefsira i kur'anske antropologije na Islamskom pedagoškom fakultetu Univerziteta u Zenici. 


\section{Uvod}

Tefsir je nauka koja se bavi izučavanjem Kur'ana časnog s ciljem otkrivanja i objašnjenja njegovih poruka ljudima. Dakle, predmet tefsira je Kur'an, koji je, shodno islamskom učenju, vječni Allahov Govor, kako po značenju tako i po jezičkoj formi koja je nosilac značenja.

Kur'an je, prema vjerovanju svih muslimana, posljednja Allahova, dž.š., Objava ljudskome rodu i glavni izvor islama u idejnom (vjerskom), zakonodavnom (pravnom) i moralnom (etičkom) pogledu. Upravo zbog toga, središnje mjesto $u$ islamu pripada Kur'anu, jer je on srž islamskog življenja i život muslimana mora biti skoncentrisan na Kur'an.

Zbog toga, tumačiti Kur'an, koji predstavlja posljednju Allahovu, dž.š., Objavu ljudima i koji je istovremeno glavni izvor islama, bez dvojbe, izuzetno je zahtjevan i odgovoran posao, budući da od tumačenja Kur'ana zavisi kako će ljudi razumjeti poruku koju im upućuje njihov Stvoritelj i Uzdržavatelj. A od toga, opet, zavisi kako će se ljudi ponašati u svome životu: ispravno ili pogrešno. Zato, tumačiti Kur'an ne može bilo ko, već to mora biti osoba koja je ispunila određene uvjete. Islamski učenjaci detaljno su pojasnili te uvjete i napisali zamašna djela u vezi s tim. ${ }^{2}$

$\mathrm{Na}$ samom vrhu pretpostavki za bavljenje tefsirom, odmah nakon ispravnosti vjerovanja (što podrazumijeva da je osoba pripadnik ehlisunneta i džema'ata), navodi se da onaj ko želi da komentariše Kur'an mora biti izvanredan poznavalac arapskog jezika, uključujući sve njegove discipline: gramatiku sa sintaksom ('ilmu-n-nahw) i morfologijom ('ilmu-s-sarf), etimologiju - porijeklo riječi ('ilmu-lištiqāq), stilistiku ('ilmu-l-belāga) sa njenim disciplinama: el-me'ānī, el-beyan i el-bedi', pa i arapsku književnost i pjesništvo (el-edeb we-šši'r), budući da je Kur'an objavljen na arapskom jeziku. U tom pogledu, istaknuti učenjak Mudžahid ibn Džebr, inače, učenik velikog tefsirskog autoriteta Ibn-Abbasa i jedan od najistaknutijih mufessira među tabi'inima, kaže: "Nikome ko vjeruje u Allaha i Budući svijet

\footnotetext{
${ }^{2}$ Opširnije o uvjetima koje mora ispuniti mufessir (komentator Kur'ana) vidjeti: dr. Safvet Halilović, Osnovi tefsira, poglavlje Pretpostavke za bavljenje tefsirom, Islamski pedagoški fakultet, Zenica, 2005., str. 33-90.
} 
(Ahiret) nije dozvoljeno da tumači Allahovu Knjigu ukoliko ne poznaje discipline arapskog jezika!" ${ }^{3}$ Učenjaci naglašavaju da nije dovoljno površno poznavanje arapskog jezika, već ono mora biti temeljito i detaljno.

U ovom radu se razmatra značaj poznavanja arapskog jezika i njegovih disciplina u pravilnom razumijevanju i tumačenju Kur'ana.

\section{Kur'an - knjiga na čistom arapskom jeziku}

Dobro poznavanje arapskoga jezika i arapske jezikoslovne nauke smatraju se temeljnim znanjima na kojima počiva tumačenje Kur'ana, jer je Uzvišeni Allah objavio Kur'an na arapskome jeziku, što se jasno vidi iz sljedećih ajeta:

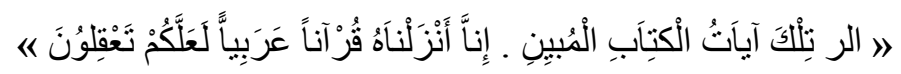

Elif Lam Ra. Ovo su ajeti Knjige jasne! Objavljujemo je kao Kur'an na arapskom jeziku da biste razumjeli. (Jusuf, ', 2)

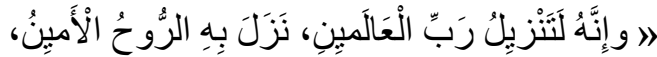

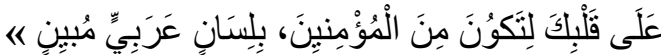

I Kur'an je sigurno objava Gospodara svjetova; donosi ga povjerljivi Džibril na srce tvoje, da opominješ, na jasnom arapskom jeziku. (ĚšŠ'ara', 193-195)

Pronicanje u značenja Kur'ana časnog i otkrivanje njegovih tajni, kao i uvid u Allahove poruke iz objavljenog Govora, ne može se ostvariti bez temeljitog poznavanja arapskoga jezika i disciplina u vezi sa jezikoslovnom naukom.

Zbog toga se u svim definicijama, u kojima su učenjaci pokušali definisati tefsir, posebno naglašava neophodnost ovladavanja arapskom jezikoslovnom naukom, zajedno sa svim njenim disciplinama, svakome ko se poduhvati komentarisanja Kur'ana. Tako, npr., Ez-Zerkeši tefsir definiše kao "nauku pomoću koje se saznaje kako treba razumijevati Allahovu Knjigu objavljenu Njegovom vjerovjesniku Muhammedu, s.a.v.s., kako tumačiti značenja njenih

\footnotetext{
${ }^{3}$ El-Kattan, Mebahis fi 'ulumi-l-Kur'an, Mektebetu Vehbe, Kairo, 1990. str, 341; EzZehebi, Et-Tefsir ve-l-mufessirun, Daru-1-kutubi-l-hadise, Kairo, 1976., tom I, str. 266.
} 
riječi, kako izvoditi njene propise i mudre poruke, pomažući se pritom znanjem iz opće jezikoslovne nauke, gramatike, sintakse, stilistike, osnova pravne nauke, različitih čitanja (učenja) Kur'ana, ne zanemarujući ni značaj pitanja povoda objave, pa ni derogirajućih i derogiranih ajeta," neophodnih za tefsir, postavlja opću jezikoslovnu nauku i njene discipline (gramatiku, sintaksu i stilistiku).

Ebu-Hajjan el-Endelusi, u predgovoru svog čuvenog tefsirskog djela El-Bahru-l-muhit, kaže: "Bavljenje tumačenjem Kur'ana može imati različite obzore kao pristupe. Prvi obzor je sa vidika jezikoslovne nauke i podjele riječi na imena, glagole i čestice. Pošto su čestice najmalobrojnije, o njihovim značenjima su govorili filolozi, pa saznanja o njima treba preuzimati iz njihovih djela. Što se tiče imena i glagola, saznanja o njima treba preuzimati iz djela opće jezikoslovne nauke. Drugi obzor je s vidika poznavanja pravila $u$ arapskome jeziku i funkciji riječi, kad su samostalne i kad su sklopljene u sekvence, a to se preuzima iz gramatike."

Prema tome, svako ko se želi baviti tumačenjem Kur'ana mora imati u vidu ono što je specifično arapskom jeziku i njegovoj građi, što odgovara njegovim pravilima i što je saglasno sa stilom Kur'ana koji je mudžiza. Uz to, mora računati i s tim da arapske riječi obuhvataju i ono što je jezik oplodio putem metafore, kao i to da jedna riječ može imati više značenja, što, također, treba znati razumijevati.

Tu je i još jedno važno pitanje na koje treba obratiti pažnju u ovom kontekstu, a to je jezik kojem se obraćamo i iz njega preuzimamo, jezik koji je bio na snazi u vrijeme objavljivanja Kur'ana. Treba imati uvid u značenje riječi toga vremena, a ne značenja koja su kasnije nastajala, jer se razvoj značenja riječi, sintagmi i rečenica odvija u skladu s tokovima vremena, zajedno s naučnim razvojem i širenjem spoznaja, popraćenim međusobnim dodirima kultura i naroda. Vremenom su neke riječi dobijale značenja koja nisu imala u vrijeme Muhammedovog, a.s., poslanstva, pa se zbog toga mjerodavnost novih značenja ne može prosuđivati prilikom komentarisanja Kur'ana, jer bi komentarisanje Allahovog, dž.š.,

\footnotetext{
${ }^{4}$ Ez-Zerkeši, El-Burhan fi 'ulumi-l-Kur'an, Daru-1-ma'rife, Bejrut, 1971., tom I, str. 13.

${ }^{5}$ Ebu Hajjan el-Endelusi, El-Bahru-l-muhit, Daru-l-fikr, Bejrut, 1977., tom I, str. 3.
} 
govora na osnovama takvih značenja i novih oznaka, bez obraćanja pažnje na izvornost jezika, odvelo u sferu nekorektnog razumijevanja Kur'ana. ${ }^{6}$

\section{Bogatstvo i širina arapskog jezika}

Arapski jezik je izuzetno bogat, kako u pogledu korijena, tako i po svojim izražajnim mogućnostima. Među svim semitskim jezicima, arapski jezik ima najviše korijena (više od 10.000 od kojih preko 6.500 trilitera), kao i najveći broj izvedenih riječi. Arapski jezik posjeduje većinu korijena koje imaju i drugi semitski jezici, ali i mnoge koje oni ne bilježe. Pored toga, arapski jezik se odlikuje izuzetno velikim brojem sinonima. Stručnjaci u oblasti arapske jezikoslovne znanosti ističu da $\mathrm{u}$ arapskom jeziku za pojam lav postoji - 500 naziva; lisica - 200; med - više od 80; sablja - najmanje 1.000; nesreća - više od 400; tako nalazimo i po 20-30 sinonima za pojmove: kiša, vjetar, svjetlo, tmina, kamen, voda, bunar, deva (tako je Hammer sakupio sve pojmove u vezi s devom i taj popis prešao je broj od 5.640 riječi). Također, neki pridjevi u arapskom jeziku imaju velik broj sinonima, poput: dug, kratak, darežljiv, škrt, hrabar, plašljiv i dr. ${ }^{7}$

Ako se u vidu ima navedeno, onda je jasno da se poznavanje oznaka kur'anskih riječi, zatim razumijevanje njihovih značenja, te otkrivanje njihovih poruka i namjera postiže upravo tefsirom. Stoga niko ne bi trebalo da se upušta u komentarisanje Allahove, dž.š., Knjige, ukoliko se nije stručno osposobio za komentarisanje koje bi trebalo počivati na temeljnim uvjetima i pravilima, od kojih je najvažnije poznavanje arapskog jezika, što $u$ sebe uključuje ovladavanje:

a) značenjima položenim $u$ riječi, njihove forme i oblike $u$ kojima riječi dobijaju funkciju oznaka različitih značenja (sintaksa);

b) pravilima o izvedenicama uzetim iz osnovnih riječi (etimologija);

${ }^{6}$ Opširnije o ovom pitanju vidjeti: Jusuf el-Karadavi, Kejfe nete'amel me'a-lKur'ani-l-'azim, Daru-š-šuruk, Kairo, 1999., str. 232-233; Rešid Rida, Tefsiru-lMenar, četvrto izdanje, Kairo, 1960., tom V, str. 301.

${ }^{7}$ Vidjeti: dr. Teufik Muftić, Gramatika arapskoga jezika, Sarajevo, 1998., str. 12. 
c) načinima tvorbe fraza i sekvenci, prema pravilima fleksije (gramatika) $\mathrm{i}$

d) onim što stoji u vezi $s$ jasnom upotrebom riječi i načinom izražavanja onog šta se riječima želi (stilistika). ${ }^{8}$

\section{Bavljenje tefsirom bez poznavanja arapske lingvistike nije dopušteno}

Bavljenje komentarisanjem Allahove, dž.s.s., Knjige, ukoliko se ne zna arapski jezik i discipline obuhvaćene njegovom jezikoslovnom naukom, veoma je štetna i opasna djelatnost, sa neželjenim posljedicama, jer aktera navodi na trusan teren, koji ga može primorati da riječi čupa iz konteksta, da drugačije shvati Allahove, dž.š., poruke iz riječi objavljenih u Kur'anu, a to može, posljedično, voditi u nevjerovanje, ateizam i izlazak iz vjere. Zato Mudžahid ibn Džebr, jedan od vodećih učenjaka i pravnika iz generacije tabi'ina, upozorava: "Nikom ko vjeruje u Allaha i Sudnji dan nije dozvoljeno da govori o Allahovoj Knjizi ukoliko ne zna arapski jezik," a Malik ibn Enes je onima koji posegnu za komentarisanjem Kur'ana bez prethodne stručne ospobljenosti zaprijetio: "Ja bih svakome ko bez stručne osposobljenosti komentariše Allahovu Knjigu propisao žestoku kaznu!" 9

El-Kurtubi u predgovoru za svoj tefsir prenosi od Ibn Ebi Mulejke (istaknuti tabi'in) predaju u kojoj se navodi da je jedan beduin u vrijeme halife Omera ibn el-Hattaba, r.a., pitao: "Ko će mi pokazati kako ću učiti ono što je objavljeno Muhammedu, s.a.v.s.?" Potom je neki čovjek poučio 3. ajet sure Et-Tevbe, na način: Innellahe beri'un mine-l-mušrikine ve Resulihi, vezujući imenicu Poslanik/Resul uz imenicu mnogobošci koja je u funkciji objekta glagola bere'e (ne priznati). Takvo učenje je u potpunosti promjenilo značenje kur'anskog teksta:

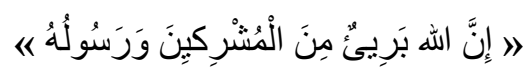

Allah $i$ Njegov Poslanik ne priznaju mnogobošce, dajući značenje: "Allah ne priznaje mnogobošce ni Svog Poslanika." Zato je

\footnotetext{
${ }^{8}$ Vidjeti: Mustafa Ibrahim el-Mišni, Medresetu-t-tefsir fi-l-Endelus, Muessesetu-rrisale, Bejrut, 1986., str. 325. i dalje.

${ }^{9}$ Navode bilježi Ez-Zerkeši u djelu El-Burhan, tom I, str. 292.
} 
beduin, kada je čuo takvo učenje, s čuđenjem upitao: "Je li moguće da Allah nije priznao Svog Poslanika?! Pa ako Allah nije priznao Svog Poslanika, onda ga ni ja ne priznajem!" Te riječi su doprle do hazretiOmera, pa je pozvao beduina i upitao ga: "Čovječe, priznaješ li ti Allahovog Poslanika, s.a.v.s.?" Beduin je odgovorio: "Vođo pravovjernih, ja sam došao u grad ne znajući ništa iz Kur'ana, pa sam pitao ko će me poučiti. Kad je taj čovjek proučio: Innellahe beri'un mine-l-mušrikine ve Resulihi (što znači: Allah ne priznaje mnogobošce i Svog Poslanika), ja sam ga pitao: "Je li moguće da Allah nije priznao Svog Poslanika, pa ako Allah nije priznao Svog Poslanika, kako ću ga ja priznati?" Omer, r.a., je tada rekao: "To nije ispravno!", potom je beduin upitao: "Pa kako je onda ispravno, vođo pravovjernih?" Omer, r.a., je odgovorio: "Pravilno je: Allah i Njegov Poslanik ne priznaju mnogobošce (Innellahe beri'un mine-l-mušrikine ve Resuluhu)." Tada je beduin rekao: "Tako mi Allaha, ni ja ne priznajem ono što ne priznaje Allah i Njegov Poslanik!" Omer ibn el-Hattab, r.a., je potom naredio da pouku iz učenja Kur'ana drže samo oni koji znaju arapski jezik. $^{10}$

Ako navedena predaja ukazuje na nešto posebno, onda je to da govor o Kur'anu i čitanje njegovih sadržaja, bez poznavanja arapskoga jezika i disciplina obuhvaćenih njegovom jezikoslovnom naukom, kao što je gramatika s fleksijom i druge, vodi na klizav teren koji može odvesti čak i u nevjerovanje i stranputicu. Zato je Vjerovjesnik, s.a.v.s., postavio putokaz i osvijetlio put pred svakim ko se želi upustiti u tako važan i dalekosežan zadatak kakav je komentarisanje Kur'ana. U hadisu koji prenosi Ebu-Hurejre, Poslanik, s.a.v.s., je rekao: "Unesite padežne oznake u Kur'an i dobro proučite neobične riječi u njemu (A'ribu-l-Kur'āne we iltemisū garā'ibehu)."11 Izraz padežne oznake (i'rāb) u ovom hadisu je, kako tvrdi Es-Sujuti u djelu El-Itkan, naziv za "nauku o (kontekstualnim) značenjima riječi, prije nego stručni termin koji koriste gramatičari nasuprot pogrešnoj

\footnotetext{
${ }^{10}$ Vidjeti: Tefsiru-l-Kurtubi, Daru-š-ša'b, Kairo, 1952., tom I, str. 41.

11 Hadis bilježi El-Hejsemi u djelu Medžme'u-z-zevaid, Mektebetu-1-Kuds, Kairo, 1934., tom VII, str. 163. Es-Sujuti ga u djelu Ed-Durru-l-mensur (tom II, str. 150) navodi s glagolom proučiti (ittebe'a umjesto iltemese).
} 
upotrebi u riječi u iskazu, a čitanje bez padežnih oznaka nije pravo čitanje niti može biti ispravno". ${ }^{12}$

Istaknuti mufessir iz islamske Španije Ebu-Abdullah el-Kurtubi, u predgovoru svog čuvenog tefsira El-Džāmi'u li ahkāmi-l-Kur'an, jedno poglavlje je naslovio s ovim naslovom: Ono što se ima reći o unošenju padežnih oznaka u Kur'an. U tom poglavlju je zabilježio nekoliko značajnih izjava istaknutnih islamskih učenjaka o spomenutom pitanju, a mi donosimo sažetak da bismo pomoću njega pružili utisak o cjelini.

Poznatom učenjaku iz generacije tabi'ina Hasanu el-Basriju rečeno je da jedna grupa uči arapski jezik, a on je na to odgovorio: "U pravu su! Uče jezik svoga Vjerovjesnika." Tada su mu sagovornici rekli: "Mi imamo imama koji pravi jezičke pogreške", a on im je na to odgovorio: "Zaustavite ga!"

Ibn-'Atijje je rekao: "Padežne oznake u Kur'anu su temelj islamskog vjerozakona, jer na njima počivaju značenja položena u vjerozakon." Ibn el-Enbari je rekao: "Od Vjerovjesnikovih drugova i tabi'ina je prenošeno sve u vezi s razumijevanjem neobičnih riječi i teških cjelina iz Kur'ana. To je potkrijepljeno primjerima iz jezika i pjesništva, kao i onim što je utvrdilo naučavanje gramatičara. Njihovo naučavanje je otklonilo nejasnoće, pobijedivši one koji su ih opovrgavali. O tome govori ono što se prenosi od 'Ikrime, koji prenosi od Ibn Abbasa da je rekao: "Ako me pitate u vezi s neobičnim riječima iz Kur'ana, onda ih dobro proučite na osnovu pjesništva, jer pjesništvo je arhiv Arapa (eš-ši'ru dīwānu-l-'Areb)". Slično je i ono što se prenosi od Se'ida ibn Džubejra i Jusufa ibn Mehrana, koji kažu: "Čuli smo Ibn-Abbasa, kad je bio upitan o nečemu iz Kur'ana, kako odgovara: 'U njemu je to tako i tako. Zar niste čuli da pjesnik kaže isto tako?"'13

Ukratko, sve navedeno se može rezimirati konstatacijom da je poznavanje arapskoga jezika jedna od osnovnih pretpostavki za bavljenje tefsirom. Zato je ispravno reći da nije dozvoljeno, niti je moguće baviti se komentarisanjem Kur'ana, ukoliko komentator ne poznaje detaljno arapski jezik, na kojem je Kur'an objavljen. To

\footnotetext{
${ }^{12}$ Es-Sujuti, El-Itkan fi 'ulumi-l-Kur'an, Daru-l-fikr, Bejrut, 1978., tom I, str. 115.

${ }^{13}$ Vidjeti: Tefsiru-l-Kurtubi, I, str. 23-24.
} 
podrazumijeva i poznavanje disciplina obuhvaćenih arapskom jezikoslovnom naukom, kao što su etimologija, sintaksa, gramatika, poetika, stilistika i dr. Upuštanje u komentarisanje Kur'ana bez ispunjenja navedenih zahtjeva veoma je štetno, jer vodi u pogrešno i iskrivljeno razumijevanje Allahove, dž.š., Knjige, a to znači u preinačavanje Allahovih, dž.š., poruka objavljenih u Kur'anu, iz čega može proisteći krivovjerstvo, nevjerovanje i izlazak iz vjere. ${ }^{14}$

\section{Značaj poznavanja arapske stilistike (el-belāga) za pravilno razumijevanje Kur'ana}

Stilistika (el-belāga) je iznošenje značenja i postizanje cilja jednostavnim, lijepim i jasnim riječima, koje obimom ne podbacuju niti prekoračuju poželjnu mjeru, koje se ne tiču ničega mimo zadatog cilja. Ako se s tim zahtjevom podudari još i tanahan smisao, neobična mudrost ili učtiv gest, to uveliko uljepšava govor i njegova značenja. $^{15}$

Poznavanje stilistike arapskog jezika od izuzetne je važnosti za tefsirsku nauku i jedna je od najneophodnijih pretpostavki potrebnih svakom ko se opredijeli za komentarisanje Kur'ana. Putem stilistike se otkriva ljepota kur'anskog izraza i stila. Ona pomaže slušaocu da akceptira srž kur'anskih poruka. Zato se lahko može uočiti da je literatura iz kur'anskih nauka krcata tvrdnjama i formulacijama koje uvjerljivo ukazuju na potrebu za posjedovanjem tog umijeća svakom ko se bavi komentarisanjem Kur'ana.

Ez-Zerkeši u djelu El-Burhan, u raspravi pod naslovom Ma'rifetu kewni-l-lafzi we-t-terkībi ahsen we ewdah, kaže: "To se preuzima iz stilistike ('ilmu-l-beyānn) i tropologije ('ilmu-l-bedī'). O

14 O tome kako istaknuti komentator Kur'ana, poput Ebu-Bekra er-Razija elDžessasa, koristi arapsku jezikoslovnu znanost i njene discipline u izvođenju brojnih šerijatskopravnih propisa iz kur'anskih tekstova vidjeti u našoj doktorskoj disertaciji pod naslovom Ebu Bekr er-Razi el-Džessas ve menhedžuhu fi-t-tefsir, koja je objavljena u Kairu (prvo izdanje 2001., drugo izdanje 2008), u izdanju poznate kuće Daru-s-selam, str. 306-369. Navedena disertacija je prevedena na bosanski jezik i objavljena (2004) u Sarajevu, u izdanju Fakulteta islamskih nauka i El-Kalema, izdavačkog centra Rijaseta Islamske zajednice u Bosni i Hercegovini. Prevodilac je prof. dr. Mehmed Kico, i u ovom radu je, na više mjesta, naročito u primjerima o arapskoj stilistici i prepjevima stihova, korišten njegov prijevod naše disertacije.

${ }^{15}$ Opširnije o stilistici vidjeti: Abdulkadir Husejn, Fennu-l-belaga, str. 61. i dalje. 
tome su napisana brojna djela i radovi. Ta nauka je jedan od veoma važnih oslonaca komentatoru Kur'ana. On mora obratiti pažnju na $\bar{l}^{\prime} d z ̌ \bar{a} z$ (nadnaravnost) kur'anskog teksta i ono što proističe iz toga, raspoznavati pravi smisao i metaforu i imati osjećaj za kompoziciju kur'anskog izraza. Mufessir mora sve to dobro poznavati da bi pravilno razumio sadržaj kur'anskog govora. Zato treba znati da je poznavanje ovog umijeća, sa svim njegovim formama i sadržajima, temelj komentarisanja koje pruža uvide u nadnaravnosti Allahovog, dž.š., govora. Ono je osnov rječitosti i konac za nisku stilskih figura."16

Brojni su aspekti stilistike koje su tretitali komentatori Kur'ana u svojim tefsirima. Na primjeru tefsirskog djela Ahkāmu-l-Kur'an (Propisi Kur'ana), poznatog hanefijskog učenjaka Ebu Bekra erRazija el-Džessasa, evidentno je da se autor bavio slijedećim aspektima stilistike:

1. pravi smisao i metafora (el-haqīqa ve-l-medžāz);

2. poređenje (et-tešbīh);

3. aluzija (el-kināye);

4. podudarnost (el-mušākele);

5. konciznost (el-ìdžāz).

U nastavku ćemo navesti nekoliko primjera iz spomenutog tefsira koji to ilustruju.

\section{Pravi smisao i metafora (el-haqīqa ve-l-medžāz)}

Istaknuti komentator Kur'ana hanefijske pravne škole Ebu-Bekr el-Džessas je pravi smisao i metaforu definisao veoma sažeto. Tako, npr., u komentaru Bismille, kaže: "Pravi smisao je riječ upotrijebljena na pravom mjestu, a metafora je ono s čim se skreće s pravog mjesta na neko drugo." ${ }^{17}$ Premda je ovdje bio koncizan, on u komentaru riječi Uzvišenoga: I pitaju te o vinu i kocki. Reci: Oni donose veliku štetu, a $i$ neku korist ljudima, samo što je šteta od njih veća nego korist (ElBakare, 219) o pravom smislu i metafori govori opširnije, navodeći

\footnotetext{
${ }^{16}$ Vidjeti: Ez-Zerkeši, El-Burhan fi 'ulumi-l-Kur'an, tom I, str. 311, 312.

${ }^{17}$ Ahkamu-l-Kur'an, Daru-1-kutubi-1-'ilmijje, Bejrut, 1994., tom I, str. 6. 
primjere iz Kur'ana za ono o čemu govori. U tom pogledu, El-Džessas ističe:

"Naziva ima dvije vrste. Jedna je ona kojom se nešto naziva po stvarnosti i izražava mu pravi smisao, a druga vrsta je ona koja je označena metaforom. Prva vrsta koristi se na mjestima gdje se zadesi, a druga vrsta onda kad postoji indikacija koja ukazuje na smisao. Primjer prve vrste su riječi Uzvišenoga: Allah želi da vam objasni $i$ da vas putevima kojima su išli oni prije vas uputi, $i$ da vam oprosti. Allah sve zna i mudar je. Allah želi da vam oprosti, a oni koji se za strastima svojim povode žele da daleko s Pravog puta skrenete (En-Nisa', 26, 27), gdje je riječ želja (irada) upotrijebljena s pravim smislom. Primjer druge vrste su Njegove riječi: I njih dvojica naiđoše na jedan zid koji samo što se nije (hoće - jurīd) srušio, pa ga onaj prezida (ElKehf, 77), gdje je riječ želja upotrijebljena kao metafora, a ne s pravim smislom. Slično je i u Njegovim riječima: Vino i kocka su (El-Ma'ide, 90), u kojima je naziv vino upotrijebljen s pravim smislom, dok je na drugom mjestu, u riječima Uzvišenoga: ja sam sanjao kako cijedim grožđe (Jusuf, 36) naziv vino upotrijebljen kao metafora, jer se tu radi o cijeđenju grožđa, a ne vina. Slično je i s riječima Uzvišenoga: Gospodaru naš, izbavi nas iz ovoga grada, čiji žitelji su nasilnici (EnNisa', 75), gdje je naziv grad (qarye) upotrijebljen s pravim smislom, za razliku od Njegovih riječi: Pitaj grad u kojem smo boravili $i$ karavanu s kojom smo došli (Jusuf, 82), gdje je upotrijebljen kao metafora, jer se nije mislilo na ono što označava naziv, već na stanovnike grada.

Pravi smisao se od metafore razlikuje po tome što se u slučaju pravog smisla ime nikako ne može odvojiti od imenovanog, jer odražava stvarnost, dok je u slučaju metafore to dopušteno. Nije li očigledno, kad bi neko rekao da 'zid nema volje', da je rekao istinu? Nije li jasno, kad bi neko rekao: 'Allah ništa ne želi' ili: 'Razuman čovjek nema volje', da bi to bile neistine? Isto tako, može se reći da sok nije vino. Međutim, ne može se reći i da ukiseljeni iscjedak grožđa nije vino. Takvih primjera je mnogo u jeziku i islamskome vjerozakonu - Šerijatu. Šerijatski nazivi koji su po svome smislu metaforički ograničavaju se na situacije koje su njima označene." ${ }^{18}$

${ }^{18}$ Ibid., I, str. 296, 297. 
Primijetili smo da El-Džessas na nekim mjestima u tefsiru, brani postojanje metafore u Kur'anu. U vezi s riječima Uzvišenoga: Samo Allahovom milošću (Fa bi ma rahma) ti si blag prema njima (Ali 'Imran, 159), on npr., kaže: "Riječ $m a$ je ovdje samo spojena zamjenica kojom se nimalo ne mijenja smisao, kao da stoji 'Fe bi rahme' bez zamjenice ma. Tako se prenosi od Katade. Slično je i u riječima Uzvišenoga: Uskoro ('an ma qalilin) će se oni pokajati (ElMu'minun, 40) i Njegovim riječima: Ali (fe bima naqdihim) zato što su zavjet prekršili (En-Nisa', 155). Jezikoslovci su o tome saglasni i tvrde da je svrha ove zamjenice intenzitet i skladnija kompozicija izraza, slično onome što je rekao El-E'aša:

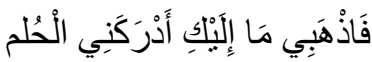

$$
\begin{aligned}
& \text { عَدَانِي عَنْ هَنْجِكُمْ إنثْفَفَقِي }
\end{aligned}
$$

Savladao me san, odlazite redom sad;

pred vašom navalom brani me moj jad.

$\mathrm{U}$ izloženom je dokaz neodrživosti tvrdnji onoga ko negira da $\mathrm{u}$ Kur'anu ima metafore, jer je upotreba riječi ma ovdje metaforična, budući da njeno otklanjanje ne bi promijenilo smisao."

Otuda vidimo da El-Džessas, tokom komentarisanja brojnih ajeta iz Kur'ana, ističe da u njima ima metafore. Navest ćemo nekoliko primjera koji to potvrđuju.

Prvi primjer: On je s početka komentara sure El-Bekare, odnosno u vezi s riječima Uzvišenoga: Oni nastoje da prevare Allaha i one koji vjeruju (ajet 9), gdje kaže: "To je u jeziku metafora, jer je prijevara u biti skrivanje, kao kad licemjer skriva mnogoboštvo (širk), a prikazuje se da ispravno vjeruje pretvaranjem, prikrivanjem i podvaljivanjem onome koga vara. Međutim, od Uzvišenog Allaha se ništa ne može sakriti i u biti ga je nemoguće prevariti. Oni koje je Uzvišeni Allah tako opisao nisu lišeni jednoga od dvoje: ili znaju da je nemoguće Uzvišenog Allaha prevariti skrivanjem, ili ne znaju, što je manje vjerovatno, jer je teško u to povjerovati, ali da tako kažemo, ipak vrše čin prijevare. Njima pripada kazna za prijevaru, čime oni sami sebe varaju. Neki kažu da se riječima: Oni nastoje da prevare Allaha želi reći: 'Oni nastoje da prevare Allahovog Poslanika', pa je ispušteno spominjanje Poslanika, kao što stoji u Njegovim riječima: 
Oni koji budu Allaha i Njegova Poslanika vrijeđali (El-Ahzab, 57), a misli se na Allahove odabranike. Koja god od dvije mogućnosti bila, to je metafora, a ne pravi smisao i ne može se koristiti nigdje osim na mjestu gdje postoji dokaz za takav smisao. Oni su varali Allahovog Poslanika iz bojazni da će ih stići ono što je stiglo ostale mnogobošce, za koje je Poslaniku i vjernicima bilo naređeno da se protiv njih bore. Vjerovatno su se zato vjernicima prikazivali da vjeruju, da vjernici s njima druguju, kao što vjernici jedan s drugim druguju, da im otkriju svoje tajne, pa da ih oni prenesu neprijateljima vjernika. Riječi Uzvišenoga: Allah ih izvrgava poruzi (El-Bekare, 15), također su metafora." 19

Drugi primjer: To je sa završetka komentara sure El-Bakare, zapravo u vezi s riječima Uzvišenoga: ko ga uskrati, srce njegovo će bit grešno, a Allah dobro zna ono što radite (ajet 283), kad kaže: "Riječi Uzvišenoga: srce njegovo će biti grešno je metafora, a ne pravi smisao, što je na ovom mjestu očigledno, jer bi pravi smisao glasio: $k o$ ga uskrati, bit će grešan, što neposrednije saopćava prijetnju, ali je to nešto iz domena nadnaravnoga kur'anskog stila i prefinjenog izražavanja smisla, neka je uzvišen Allah Mudri." ${ }^{20}$

Treći primjer: U suri El-Ma'ide, kad govori o riječima Uzvišenoga: Gospodaru moj, reče (Musa), ja osim sebe imam moć (la emliku illa) samo nad bratom svojim (ajet 25), gdje kaže: "Ovo je metafora, jer čovjek u pravom smislu nema vlast ni nad sobom ni nad bratom slobodnjakom, zato što je u osnovi vlasti moć, a nemoguće je da čovjek vlada nad sobom i svojim bratom. Naziv vlast je ovdje primijenjen na ponašanje, pa je ono što se posjeduje stavljeno na poziciju onog što obuhvata moć, budući da je mogao njime upravljati kao onim što je obuhvaćeno njegovom moći. Ovdje to znači da on posjeduje sposobnost kontrole svog ponašanja u pokornosti Allahu, a primjenjuje je i na svog brata, jer se ponaša u skladu s njegovim zapovijedima i onim što on kaže." 21

Četvrti primjer: Ovaj primjer je iz sure El-Isra', i odnosi se na riječi Uzvišenoga: Budi prema njima pažljiv i ponizan (ajet 24), gdje El-Džessas kaže: "Riječi Uzvišenoga: Budi prema njima pažljiv $i$

\footnotetext{
${ }^{19}$ Ibid., I, str. 29.

${ }^{20}$ Ibid., I, str. 649.

${ }^{21}$ Ibid., II, str. 501.
} 
ponizan su metafora, jer poniznost (dhull) nema krila, niti se po tome opisuje, već se time želi naglasiti poniznost $i$ pažnja prema roditeljima, kao u versifikaciji Imru'u-1-Kajsa kad opisuje noć:

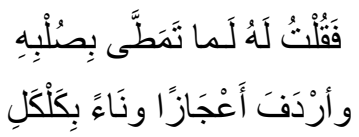

Rekao sam vam da je glatka kao šipka,

širokih ramena, stasa visoka i vitka -

budući da noć nije gvožđe, niti ima bedra, ni prsa, jasno je da je to metafora, s kojom se želi postići sklad i uravnoteženost." ${ }^{22}$

\section{Pozivanje na pravi smisao i metaforu}

Čitalac djela Ahkamu-l-Kur'an će primijetiti da se El-Džessas u brojnim područjima poziva na pravi smisao i metaforu (haqīqa i medžaz), posebno prilikom izvođenja fikhskih propisa, zatim povodom stavova oprečnih odredbama njegovog mezheba te $\mathrm{u}$ vezi $\mathrm{s}$ pitanjima vjerovanja.

Primjer prve vrste, tj. pozivanje na pravi smisao i metaforu $\mathrm{u}$ području izvlačenja fikhskih propisa, jeste ono što je rekao u komentaru riječi Uzvišenog Allaha: I ne ženite se sa ženama s kojima su se ženili očevi vaši (En-Nisa', 22), gdje je zahvatio upotrebu riječi brak (nikāh) sa stanovišta jezika navodeći tvrdnje jezikoslovaca da "brak u jeziku izvorno znači sastavljanje jednog s drugim", nakon čega navodi stihove po kojima je "naziv brak (nikah) pravi smisao za spolni snošaj, a metafora za ugovor".

Nakon toga veli: "Nakon što se potvrdilo ono što smo istaknuli, da naziv obuhvata oboje - ugovor i spolni snošaj, potvrdila se i prosudba da naziv u jezičkoj zbilji označava sastavljanje jednog $\mathrm{s}$ drugim. Sastavljanje može biti samo putem spolnog snošaja, a ne i putem ugovora, jer se u sklopu ugovora ne ostvaruje sastavljanje, budući da je to zajednička izjava dvije strane u ugovoru, koja, u zbilji, ne podrazumijeva sastavljanje. Time se potvrđuje da naziv nikah ima pravi smisao spolnog snošaja, a metafora je za ugovor. Ugovor je nazvan nikahom, zato što je osnova i sredstvo koje vodi do spolnog

${ }^{22}$ Ibid., III, str. 256. 
snošaja, što predstavlja nazivanje nečega tuđim imenom, a to što je njegov uzrok ili mu je blisko, kao što se npr. kosa s kojom se dijete rodi naziva 'aqiqa, pa je potom i ovca, koja se kolje prilikom podrezivanja kose djeteta, nazvana 'aqiqa, kao što se i riječ rawiya (vodonoša), koja je naziv i za devu koja nosi mješinu za vodu, počela koristiti za samu mješinu zbog veze i bliskosti s devom. Slično je s kutkom (ga'it), nazivom za skrovito mjesto na zemlji, koji kao metafora može označavati i ljudski izmet, jer se naziv skrovito mjesto koristio kao oznaka za mjesto na kojem se može obaviti fiziološka potreba. Sličnih primjera je mnogo. Tako je i brak (nikah), u zbilji, naziv za spolni snošaj, shodno svojoj temeljenoj jezičkoj upotrebi tog pojma, a primjenjuje se, kao metafora, i za ugovor, jer se putem ugovora, kao osnove i sredstva, stiže do spolnog snošaja. (...) Tako postaje jasno da naziv nikah, u pravom smislu, označava spolni snošaj, a kao metafora označava ugovor." Ako uzmemo u obzir sve što smo rekli, riječi Uzvišenoga: I ne ženite se sa ženama sa kojima su se ženili očevi vaši pretpostavljaju spolni snošaj. Zabranjuje im se spolni snošaj sa ženom s kojom je snošaj imao njihov otac. S obzirom na to da je nikah naziv za spolni odnos, to se općenito odnosi i na dozvoljen i na zabranjen odnos, osim ako postoji dokaz da se ograničava na jedno od to dvoje." 23

Kao primjer za drugu vrstu, tj. pozivanja na pravi smisao i metaforu, prilikom prigovora stavovima drugačijim od stavova njegovog mezheba, može poslužiti ono što El-Džessas ističe u komentaru riječi Uzvišenog Allaha: obavite umru do hadža i zakoljite kurban do kojega možete lahko doći (El-Bekare, 196), kad kaže: "Ova povlastica koja se odnosi na obavljanje umre važi samo za onog ko nije iz Mekke, u skladu s Njegovim riječima: To je za onoga ko nije iz Mekke. Onaj ko živi u zoni između mikata i Mekke nema pravo sukcesivnog obavljanja umre, pa onda hadža (temettu'), niti istovremenog obavljanja hadža i umre (kiran), stanovište je učenjaka našeg mezheba - jer, ako istovremeno obavi hadž i umru, ili samo umru, pogriješit će. Ta osoba dužna je zaklati kurban, ali ne smije jesti njegovo meso, zato što se taj kurban ne kolje zbog temettu' hadžadž, već zbog učinjene greške, budući da nema temettu'a za onoga ko je iz tih mjesta, u skladu s riječima Uzvišenoga: To je za onoga ko nije iz

${ }^{23}$ Ibid., II, str. 141, 142. 
Mekke. Od Ibn-'Umara se, pak, prenosi da je rekao: 'Temettu' je olakšica onome ko nije iz Mekke.'

Neki kažu: 'To znači da oni koji nisu iz Mekke, nisu dužni pustiti krv ako čine temettu'. Prema tome, oni temettu' mogu obavljati bez kurbana'. Međutim, ono što se iz ovog ajeta jasno vidi suprotno je onom što takvi vele, budući da je Uzvišeni rekao: To je za onoga ko nije iz Mekke, čime se u vidu ima temettu'. Da se u vidu imao kurban, bilo bi rečeno: 'To je obaveza za onog ko nije iz Mekke'. Ako bi neko rekao: Moguće je da to znači: 'To je obaveza za onoga ko nije iz Mekke, zato što je tu partikula li došla na mjestu partikule 'ala, kao kad Uzvišeni kaže: Njima slijedi prokletstvo i najgore prebivalište $\left(E r-R a^{\prime} d, 25\right)$, gdje partikula $l i$ ima smisao partikule 'a $a^{\prime}, \mathrm{mi} \mathrm{mu}$ odgovaramo: 'Nije moguće odvojiti riječ od njenoga stvarnog značenja i dati joj metaforičko značenje bez indikacije za takav postupak. Svako od tih (jezičkih) sredstava ima svoj stvarni smisao. Stvarnost partikule 'ala razlikuje se od stvarnosti partikule $l i$, te nije moguće da joj se daje drugo značenje bez dokaza. Tako je i umra, za žitelje krajeva udaljenih od Mekke, olakšanje kojim im Uzvišeni Allah otklanja teškoće, kakve bi imali da se poduhvataju posebnog putovanja za umru, a posebnog za hadž. Dozvolio im je da to svedu na jedno putovanje za oba obreda. Kada bi to bilo zabranjeno, vodilo bi teškoćama i izdacima za njih. Što se tiče stanovnika Mekke, za njih nema poteškoća niti posebne štete da umru obavljaju i mimo vremena hadža."'24

Primjer treće vrste, tj. pozivanja na pravi smisao i metaforu, u vezi s nekim pitanjem iz područja vjerovanja naći ćemo u komentaru Allahovih (dž.š) riječi: Čekaju li oni da im Allahova kazna dođe iz vedra neba, i meleki (El-Bekare, 210), kad kaže: "Ovo je jedan od manje jasnih ajeta. Allah je zapovijedio sravnjavanje tog ajeta $\mathrm{s}$ Njegovim jasnim riječima: On tebi objavljuje Knjigu. U njoj su ajeti jasni, a oni su glavnina knjige, a drugi su manje jasni. Oni čija su srca pokvarena, željni smutnje i svog tumačenja, slijede one što su manje jasni (Ali 'Imran, 7). On je manje jasan po tome što se dolazak (ityan) može shvatiti s pravim smislom, a može se pretpostaviti i da se njime misli na Allahovu zapovijed i isticanje Njegovih jasnih znakova, kao u Njegovim riječima na drugom mjestu: Zar oni čekaju da im

${ }^{24}$ Ibid., I, str. 348, 349. 
meleki dođu, ili kazna Gospodara tvoga, ili neki predznaci od Gospodara tvoga (El-En'am, 158). Svi ti ajeti su manje jasni i sadrže ono što Uzvišeni naglašava u riječima: ili će tvoj Gospodar doći (ew ye'tiye Rabbuke), budući da Uzvišenom Allahu nije svojstven dolazak i odlazak, niti premještanje ili silazak, jer su to svojstva tijela i aspekti pojavnosti. U jednome jasnom ajetu Uzvišeni kaže: Niko nije kao On (Ěs-Šura, 11). Ibrahimu, a.s., je kretanje i premještanje zvijezda načinio dokazom pojavnosti, koji je on iznosio svome narodu kao argument. Uzvišeni Allah kaže: To su naši dokazi koje donosimo Ibrahimu za narod njegov (El-En'am, 83), znači - u pojavnosti zvijezda i tijela. Allah je neizrecivo daleko od onog što tvrde oni koji Allaha porede sa stvorenjima.

Ako bi neko pitao: 'Može li se reći: 'Došao je tvoj Gospodar', sa smislom: 'Došla je Njegova Knjiga', ili: 'Došao je Njegov Poslanik' ili slično tome, odgovaramo mu: 'To je metafora. Metafora se upotrebljava samo na mjestu gdje postoji dokaz koji ukazuje na njen smisao. Uzvišeni je rekao: Pitaj grad u kojem smo boravili i karavanu s kojom smo došli (Jusuf, 82), pri čemu se misli na stanovnike grada. Rekao je i: One koji budu Allaha i Poslanika Njegova vrijeđali (El$A h z a b, 57)$ što znači - Allahove odabranike. Metafora se upotrebljava na mjestu na kojem može počivati smisao kad se upotrijebi, ili u nečemu što za slušaoca neće imati nejasno značenje." 25

\section{Neka pravila koja se odnose na pravi smisao i metaforu}

$\mathrm{Na}$ prethodnim primjerima čitalac će primijetiti da El-Džessas postavlja važna pravila koja treba uzeti u obzir prilikom pozivanja na pravi smisao i metaforu. S ciljem da upotpunimo izlaganje o tom pitanju, a iz opreza da ne duljimo, naznačena pravila ćemo samo sumarno nabrojati.

Prvo pravilo: "Nije dozvoljeno riječ odvojiti od stvarnog značenja i dati joj metaforičko značenje, osim ako postoji indikacija koja ukazuje na smisao." ${ }^{26}$

\footnotetext{
${ }^{25}$ Ibid., I, str. 385, 386.

${ }^{26}$ Ibid., I, str. 348.
} 
Drugo pravilo: "Metafora se upotrebljava na mjestu za koje postoji dokaz da se tu upotrebljava ili u nečemu što za slušaoca neće imati nejasno značenje." 27

Treće pravilo: "Jedna riječ ne može istovremeno imati pravi smisao i biti metafora, niti može biti istovremeno jasan izraz i aluzija." ${ }^{28}$

Četvrto pravilo: "Nije dozvoljeno korištenje neke metafore, a da je Arapi nisu čuli, ili da je šerijat nije usvojio."${ }^{29}$

\section{Poređenje (et-tešbīh)}

Jedan od aspekata stilistike na koje je autor djela Ahkamu-lKur'an obratio pažnju u tefsiru jeste poređenje (et-tešbīh). Međutim, pažnja koju je posvetio tom aspektu stilistike ne može se uporediti s pažnjom koju je posvetio pravom smislu i metafori, ni sa stanovišta obima, niti dubine analize, jer je poređenje neuporedivo manje zastupljeno. Preciznije, El-Džessasovo bavljenje tim aspektom stilistike svodi se na formu ukazivanja na to da u nekim ajetima iz Kur'ana ima poređenja, a da o tome ništa detaljno ne kaže, niti se na to poziva, za razliku od razmatranja pravog smisla i metafore, prilikom izvlačenja fikhskih propisa, posebno povodom stavova oprečnih njegovim stavovima o raznim fikhskim pitanjima.

Primjer onog što se ovim povodom može spomenuti jeste sadržaj komentara riječi Uzvišenoga: Allah njih izvrgava poruzi $i$ podržava ih da u svom nevjerništvu lutaju (El-Bekare, 15), u kojem interpretira nekoliko vrsta tumačenja ovog ajeta i ističe: "Kažu: 'To je tako iznio Uzvišeni Allah, putem poređenja, a to znači da, s obzirom na to da se njima vraćaju posljedice od poruge i za njih se vežu, da se upravo njima rugalo'. Kažu i: 'Ako im je odgođeno na ovom svijetu i nije ih odmah stigla kazna, kao ostale mnogobošce, pa su tim odlaganjem obmanuti, to je bio neki vid poruge na njihov račun." ${ }^{30}$

Takav primjer je i ono što je istaknuto u komentaru riječi Uzvišenog Allaha: Ako ih otpustite prije nego što ste u odnos s njima

\footnotetext{
${ }^{27}$ Ahkamu-l-Kur'an, I, str. 386.

${ }^{28}$ Ibid., II, str. 468.

${ }^{29}$ Ibid., II, str. 188.

${ }^{30}$ Ibid. I, str. 30 .
} 
stupili, a već ste im vjenčani dar odredili (El-Bekare, 237), gdje kaže: "Pod pojmom feradtum ovdje se misli na određivanje iznosa vjenčanog dara i njegovo definisanje ugovorom. Otuda se i visina zekata na deve (feraidu-l-ibil) propisuje u skladu s brojem deva i starošću. Ovdje je ta procjena nazvana razrezivanjem (fard), zbog poređenja sa razrezom na strelici koji se raspoznaje od ostalog. Sličan je put ustanovljenja mjera i u drugim pitanjima, na osnovu čega je nastalo raspoznavanje tih od preostalih količina." ${ }^{31}$

Slično je i s onim što nalazimo u komentaru riječi Uzvišenog Allaha: Kazna za one koji protiv Allaha i Poslanika Njegova vojuju $i$ koji nered na Zemlji čine (El-Ma'ide, 33), tim povodom ističe da u tom ajetu ima i metafore i poređenja, naglašavajući: "Njegove riječi koji protiv Allaha vojuju su metafora, a ne pravi smisao, jer nije svojstveno Allahu da ratuje. To podrazumijeva dva smisla: prvi je što su oni koji javno izlaze, pokazuju oružje i presijecaju put, u istom rangu s onima koji se protiv drugih bore, pa su nazvani tako putem poređenja s onima koji se bore protiv drugih ljudi, kao što je Uzvišeni rekao: Zato što oni rade protiv Allaha i Poslanika Njegova, a onoga ko radi protiv Allaha i Poslanika... (El-Enfal, 13) i: Oni koji se suprotstavljaju Allahu i Poslaniku Njegovu... (El-Mudžadele, 20). Smisao rada protiv (mušaqqa) je da svaki od dvojice ide na svoju stranu i radi protiv svog druga, a smisao suprotstavljanja (muhadda), da svaki od dvojice ide do krajnosti u razdvajanju. To ne može biti svojstveno Uzvišenom Allahu, jer On nije na nekom određenom mjestu na kojem radi protiv ili se suprotstavlja, niti je moguće razilaziti se i odvajati se od Njega. Tu se radi o poređenju sa zavađenima, jer se svaki od dvojice našao na nekoj strani ili mjestu nasuprot drugome. To je stilski izraz za ispoljavanje razmirica $\mathrm{i}$ suprotstavljenosti. Slično i u riječima Uzvišenoga: oni (koji) rade protiv Allaha, treba pretpostaviti da su tako opisani na osnovu toga što se uporede s onima koji ispoljavaju suprotstavljenost drugima $\mathrm{i}$ bore se protiv njih.

Ta grupa je tako nazvana zbog izlaska $s$ isukanim oružjem, uvjerena u svoju moć, da bi kršila zapovijedi Uzvišenog Allaha i radila ono što je zabranjeno. Tako nije nazvan svako ko griješi prema Allahu, jer nije svako u takvom rangu sprečavanja i pretjerivanja, kao

${ }^{31}$ Ibid., I, str. 527. 
što su otimanje imovine i presijecanje puta. Moguće je da se ovdje misli općenito, na one koji rade protiv Allaha i Njegovih odabranika, kao kad je Uzvišeni rekao: One koji Allaha i Poslanika Njegova budu vrijeđali (El-Ahzab, 57), što znači: vrijeđali Allaha i Njegove odabranike. To općenito znači: ukoliko rade protiv Allahovog Poslanika oni su odmetnici koji ispoljavaju suprotstavljenost Allahovom Poslaniku, s.a.v.s." ${ }^{32}$

\section{Aluzija (el-kināye)}

Jedan od aspekata stilistike jeste i aluzija (el-kināye). Taj pojam u jeziku izvorno znači sakrivanje (setr). Kad se nešto aludira, to se donekle prikriva. Neki učenjaci su aluziju definisali kao "izražavanje pogrdnog značenja lijepim riječima, nečega prljavoga čistim, jer Arapi između sebe, obično, ne kriju ništa osim onog čije spominjanje izaziva gnušanje". Drugi su je definisali kao "prelazak s jasnog izraza o nečemu na nešto što mu je približno i obuhvatanje njime onoga što je nužno". ${ }^{33}$

Prilikom čitanja djela Ahkamu-l-Kur'an naći ćemo brojna mjesta na kojima El-Džesssas ukazuje na prisustvo aluzije. Navest ćemo sljedeća tri:

Prvo mjesto je ono gdje nalazimo komentar riječi Uzvišenoga: Zato se sada sastajte s njima (El-Bekare, 187), gdje kaže: "Riječi Uzvišenoga Zato se sada sastajte s njima su dozvola za spolno općenje koje je bilo zabranjeno u noćima dok post traje. Mubašara (riječ upotrijebljena u ajetu) je međusobni dodir dviju (ljudskih) koža, a ovdje je to aluzija na spolno općenje. Zayd ibn Aslam je rekao: 'To je ljubavna igra i spolno općenje.' Za sastajanje je jednom prilikom rekao: 'To je dodir kože s kožom.' Hasan el-Basri je rekao: 'Sastajanje je spolni snošaj (nikah),' a Mudžahid je rekao da je to spolno općenje, poput onog što se navodi u riječima Uzvišenoga: $S$ njima ne smijete imati snošaja dok ste u i'tikafu u džamijama (El-Bekare, 187)."34

\footnotetext{
${ }^{32}$ Ibid., II, str. 508.

33 O tim definicijama vidjeti: Abdulkadir Husejn, El-Kur'an we-s-suweru-lbeyaniyye, II, str. 259.

${ }^{34}$ Vidjeti: Ahkamu-l-Kur'an, I, str. 276.
} 
Drugo mjesto je označeno El-Džessasovim komentarom na riječi Uzvišenoga: Vaše žene su njive vaše $i$ vi njivama vašim prilazite kako hoćete (El-Bekare, 223), gdje kaže: "Njiva (harl) je oranica, a na ovom mjestu je taj pojam upotrijebljen kao aluzija na spolno općenje. Žene su nazvane njivama, jer su one oranice u koje se polaže sjeme iz koga će iznuknuti djeca. Kad Uzvišeni kaže: vi njivama vašim prilazite kako hoćete, to znači da se dozvola spolnog snošaja svodi na prodiranje u vulvu, budući da je to mjesto zasijavanja." ${ }^{35}$

Treće mjesto donosi osvrt na suru En-Nisa', preciznije, komentar na riječi Uzvišenoga: Kad neka od žena vaših blud počini, zatražite da to protiv njih četverica od vas posvjedoče $\left(E n-N i s a^{\prime}, 15\right)$ i Njegovih riječi: A ako dvoje to učine, izgrdite ih (En-Nisa', 16) gdje, pozivajući se na prisustvo aluzije u njima, kritikuje ono što se u vezi s objavljivanjem dva ajeta prenosi od Hasana el-Basrija: "U vezi s njihovim redoslijedom postoje dva stava. Jedan je onaj koji se prenosi od Hasana el-Basrija, da je ajet: $A$ ako dvoje to učine, izgrdite ih, objavljen prije ajeta: kad neka od žena vaših blud počini, a nakon toga je naređeno da se čita poslije njega, kao da je grdnja dvoje zajednička kazna za oboje prijestupnika, nakon koje slijedi zatvor za ženu. To je daleko od mogućeg, jer je zamjenica to u riječima Uzvišenoga: $A$ ako dvoje to učine, aluzija i nužno je da ima nešto vidljivo što je spomenuto u saopćenju ili kao konkretno poznato sagovorniku, a u riječima Uzvišenoga: $A$ ako dvoje to učine, izgrdite ih, nema znaka koji dokazuje da se ima u vidu blud. Aluzija se ovdje može odnositi samo na blud čije je spominjanje prethodilo (u prvom ajetu), a da ne aludira na blud, iskaz ne bi bio korektan niti bi mogao saopćiti željeno. To željeno, ovdje nije u rangu s onim što je namjera riječi Uzvišenog: Ništa živo na njenoj površini neće ostaviti (Fatir, 45) i Njegovim riječima: Mi smo ga objavili u noći Kadr (El-Kadr, 1), jer se iz samog objavljivanja podrazumijeva Kur'an, a iz ukupnog smisla riječi Uzvišenoga: Ništa živo na njenoj površini neće ostaviti, razumije se da se radi o Zemlji. Dakle, da bi se željeno izrazilo aluzijom, neophodna je oznaka stvarnog stanja i znanje sagovornika o tome šta se time želi. Ako se u obzir uzme vidljivo u govoru, te neupitnost da redoslijed značenja ajeta bude u skladu s redoslijedom riječi, proizlazi da su dva ajeta objavljena zajedno, ili da je onaj o grdnji objavljen

${ }^{35}$ Ibid., I, str. 425. 
nakon onog o zatvaranju žene ako se, kada je riječ o grdnji, u vidu ima ista žena na koju se odnosi zatvaranje. Drugi stav je se prenosi od AlSuddija, da su riječi Uzvišenoga: $A$ ako dvoje to učine, izgrdite ih, propis, prvenstveno za neudate žene i neoženjene muškarce, a prvi ajet za udate ili udavane žene, samo što takav stav zahtijeva specificiranje izraza bez dokaza, što nije dozvoljeno nikome ako postoji mogućnost upotrebe oba izraza u njihovom stvarnom značenju. Bez obzira na to koja od mogućnosti tumačenja normi i redoslijeda ovih ajeta bila odabrana, među učenjacima nema razilaženja o tome da su dva propisa koji se odnose na počinioce bluda derogirana." ${ }^{36}$

\section{Podudarnost (el-mušākele)}

Podudarnost je, zapravo, jedan od aspekata tropologije. Stilističari su je definisali kao "isticanje nečega riječju kojom se označava nešto drugo, po tome što se to našlo pored toga drugog, bilo objektivno ili po procjeni". ${ }^{37}$ El-Džessas el-mušăkelu naziva "susretom riječi s nekom sličnom riječju i uparivanjem s njom". ${ }^{38}$

Na primjer, u komentaru riječi Uzvišenoga: Allah ih izvrgava poruzi (El-Bekare, 15), dok izlaže ovaj aspekt stilistike, ističe: "Tako su i riječi Uzvišenoga Allah ih izvrgava poruzi, metafora kojom se iskazuje više smislova. Na jednoj strani je susret riječi sa sličnom, premda ne istog značenja, kao i u riječima Uzvišenoga: Nepravda se može uzvratiti istom mjerom. (Ě̌šSura, 40) Drugi smisao je u tome što se zlo susrelo s dobrim pa, pošto se dobro našlo naspram zla, na njega se prelijeva značenje prvoga. U riječima Uzvišenoga: Onima koji vas napadnu uzvratite istom mjerom (El-Bekare, 194) drugi sudionik iz para nije napadač. U riječima Uzvišenoga: Ako hoćete da na nepravdu uzvratite, onda učinite to samo u onolikoj mjeri koliko vam je učinjeno (En-Nahl, 126), prvo nije nepravda, već u susretu s onim što je označeno takvom riječju postaje podudarno i upareno. Arapi kažu: 'Nagrada za nagradu', premda prvo nije nagrada. Pjesnik veli:

\section{أَلَا لاَ يَجْهَانَنَّ أَحَدُ عَلَيْنَا \\ فَنَجْهَلَ فَوْقَ جَهْلِ الْجَاهِلِينَاً}

\footnotetext{
${ }^{36}$ Ibid., II, str. 134.

${ }^{37}$ El-Džurdžani, El-Išarat ve-t-tenbihat fi 'ilmi-l-belaga, str. 267.

${ }^{38}$ Ahkamu-l-Kur'an, I, str. 30.
} 


\section{Pretvara se da nas zaboravio}

niko od nas ga nije pozdravio

gdje je jasno da se ne hvali grubo ponašanje, ali je ono došlo nasuprot drugoj, parnoj riječi." 39

Slične naravi je i ono što El-Džessas ističe povodom završetka sure El-Bekare, odnosno u komentaru riječi Uzvišenog Allaha: Gospodaru naš, ne kazni nas ako zaboravimo ili što nehotice učinimo (El-Bekare, 286) gdje kaže: "Zaborava ima dvije vrste. Jedna vrsta je kad je čovjek u situaciji da uradi nešto što se lahko zaboravlja, te je poželjno ispričati se, ako dođe do kakvog prekršaja iz nehata. Druga vrsta je kad zaborav ima smisao ostavljanja onog što je naređeno, zbog sumnje koja iskrsne ili zbog nedovoljnog razumijevanja, makar se predmetni čin i ne desio kao rezultat zaborava, pa je poželjno od Allaha tražiti oprost za djela počinjena na takav način. Zaborav $u$ smislu ostavljanja poznat je u jeziku. Uzvišeni kaže: zaboravljaju Allaha pa je $i$ on njih zaboravio (Et-Tevbe, 67), što znači: ostavili su Allahovu, dž.š., zapovijed i ne zaslužuju nagradu. Zaborav je ovdje pripisan Allahu po osnovi susretanja i uparivanja, kao i u riječima Uzvišenoga: Nepravda se može uzvratiti istom mjerom, i Njegovim riječima: Onima koji vas napadnu uzvratite istom mjerom." 40

\section{Konciznost (el-īdžāz)}

Među aspektima stilistike ne koje je El-Džessas obratio pažnju i kojim je dokazivao da je Kur'an Objava Uzvišenog Allaha jeste i konciznost (el-îdžâa). Neki stilističari su $\bar{l} d \check{z} \bar{a} z$ definisali kao "reduciranje govora bez povrede smisla" ili "izražavanje opsežnog smisla malim brojem riječi". 41

Jedan od primjera na čijim osnovama možemo vidjeti domete El-Džessasovog zanimanja za zastupljenost ove stilske forme $\mathrm{u}$ Kur'anu jeste ono što je napisao u komentaru riječi Uzvišenog Allaha: A ako je opet pusti, ona mu se ne može vratiti što se neće za drugoga muža udati (El-Bekare, 230), gdje kaže: "U Riječi Uzvišenoga: A ako je opet pusti, ona mu se ne može vratiti što se neće za drugog muža

\footnotetext{
${ }^{39}$ Ibid., I, str. 29, 30.

${ }^{40}$ Ibid., I, str. 652.

${ }^{41} \mathrm{O}$ ovim definicijama vidjeti: Abdulkadir Husejn, op. cit., str. 177, 178.
} 
udati, ukomponovano je nekoliko značenja. Jedno značenje je zabrana da se (žena) uda za onog ko ju je s tri izričaja otpustio, sve dok se ne uda za drugoga; drugo značenje je da se kao uvjet uklanjanju zabrane onome ko je izrekao trostruko otpuštanje propisuje i ugovor i spolni snošaj zajedno, jer je nikah u pravom smislu spolni snošaj, a spominjanje supružnika ukazuje na ugovor. To bi bila konciznost i reduciranje na razumljivu aluziju koja zamjenjuje ono što sadrži jasan izraz. Od Vjerovjesnika, s.a.v.s., su sačuvane jasne predaje o tome kako otpuštena žena nije dozvoljena prvome dok s njom spolni snošaj ne bude imao njen drugi zakoniti muž." ${ }^{42}$

Slično je i ono što El-Džessas navodi u komentaru riječi Uzvišenoga: Redovno namaz obavljajte, naročito onaj krajem dana (wusta), i pred Allahom ponizno stojte (El-Bekare, 238), kad kaže: "Riječi Uzvišenoga: i pred Allahom ponizno stojte, sadrže naredbu da se mirno stoji. Nakon što je riječ poniznost (qunut) bila naziv za pokornost ( ta' $^{\prime}$ ), ustanovljeno je da su sve radnje u namazu pokornost, da pokornosti nije lišena nijedna radnja, tim prije što poniznost znači i ustrajnost $\mathrm{u}$ nečemu. Tome je pridodana zabrana razgovora, koračanja, ležanja, jela, pića i svake druge radnje koja nije sakladna pokornosti. Nakon što je ta riječ obuhvatila ustrajnost u pokornostima, koje čine radnje u namazu, te zabranu da se one prekidaju drugim radnjama koje nisu sakladne pokornosti i ustrajnosti u njoj, uključila je u sebe i ustrajnost u skrušenosti i smirenosti, jer sama riječ i to obuhvata. Tako je ta riječ, unatoč malom broju fonema koje sadrži, obuhvatila sve radnje u namazu, sve što se izgovara (dikr), sve obavezne (mefrud) i preporučene (mesnun) dijelove, podrazumijevajući zabranu svih radnji u kojima nema manifestacije pokornosti."43

\section{Dokazivanje konciznošću i stilom da je Kur'an Božija Objava}

Jedna od vrijednosti El-Džessasovog pristupa jeste i to što je on konciznošću kur'anske riječi i stilistikom zastupljenom u Kur'anu, zajedno s njegovom jezgrovitošću, te mnogostrukim smislovima, dokazivao da je Kur'an Allahova, dž.š., Objava, i nije djelo čovjeka. Takav primjer je ono što je napisao u komentaru ajeta o dugovanju,

\footnotetext{
${ }^{42}$ Ahkamu-l-Kur'an, I, str. 472.

${ }^{43}$ Ibid., I, str. 545.
} 
gdje opširno tumači njegove detaljne poruke u vezi za raznovrsnim fikhskim propisima i pitanjima. Prilikom prolaska kroz poruke riječi Uzvišenoga: koje prihvatite kao svjedoke (El-Bekare, 282) detaljno govori o uvjetima koje treba da ispune svjedoci. U vezi s tim on kaže:

"To su te tri osobine koje smo isticali: pravednost, neosumnjičenost i nesklonost zaboravljanju. To su bitni uvjeti svjedočenja. Sve su ih obuhvatile riječi Uzvišenoga: koje prihvatite kao svjedoke. Treba sagledati mnoštvo smislova i korisnih uputstava o propisima koji su obuhvaćeni riječima Uzvišenoga: koje prihvatite kao svjedoke, uprkos malom broju slova, zahvaljujući njihovom stilskom poretku, konciznosti i vidljivim značenjima. Sve što smo istaknuli o značenjima tih riječi, preuzeto iz stavova ranijih i kasnijih generacija učenjaka, zajedno $\mathrm{s}$ njihovim poniranjem $\mathrm{u}$ značenja riječi $\mathrm{i}$ nastojanjem da budu saglasna sa sadržinom pojma, uz činjenicu da ih izraz podrazumijeva, dokazuje da je to govor Uzvišenog Allaha. Prvenstveno stoga što nije u moći stvorenja ustanovljenje riječi koje bi obuhvatile značenja, dokaze, smislove i mudrosti koje obuhvataju ove riječi, uprkos njihovoj sažetosti i malom broju slova. Dakako, ostala su još mnoga njihova značenja koja naša znanja nisu obuhvatila, što će zahtijevati još mnogo truda i vremena prilikom pisanja o njima. Allaha molimo da nas pomogne da saznamo mudrosti i poruke Njegove Knjige, da Mu budemo sasvim privrženi." 44

\section{Zaključak}

Tumačiti Kur'an, koji predstavlja posljednju Allahovu, dž.š., Objavu ljudima i koji je istovremeno glavni izvor islama, izuzetno je zahtjevan i odgovoran posao. Zbog toga su islamski učenjaci kazali da je za validno bavljenje tefsirom potrebno ovladavanje nizom naučnih disciplina, koje su, zapravo, mehanizmi zaštite od krivog i tendencioznog tumačenja Kur'ana.

Jedan od glavnih uvjeta koje mora ispuniti mufessir je temeljito poznavanje arapskog jezika $\mathrm{i}$ arapske jezikoslovne znanosti sa svim njenim disciplinama: gramatika sa sintaksom ('ilmu-n-nahw) i

\footnotetext{
44 Ahkamu-l-Kur'an, I, str. 620, 621. Iz navedenih riječi se vidi El-Džessasova skromnost, jer je samo naznačenom dijelu ajeta o dugovanju posvetio više od deset gusto ispisanih stranica.
} 
morfologijom ('ilmu-s-sarf), etimologija - porijeklo riječi ('ilmu-lištiqaq), stilistika ('ilmu-l-belāga) sa njenim disciplinama: el-me'ānī, el-beyān i el-bed', kao i arapska književnost i pjesništvo (el-edeb we$\check{s}$-ši'r), s obzirom da je Kur'an časni objavljen na arapskom jeziku. Upravo zbog toga je potrebno da veliku pažnju posveti arapskom jeziku, njegovom učenju i temeljitom ovladavanju, svako ko želi da tumači Allahovu, dž.š., knjigu - Kur'an časni.

\section{Literatura:}

1. Abdulkadir Husejn: El-Kur'an we-s-suweru-l-beyāniyye, Daru-l-menar, Kairo, 1991.

2. Abdulkadir Husejn: Fennu-l-belāga, Alemu-l-kutub, Bejrut, drugo izdanje, 1984.

3. Džessas, Ebu Bekr er-Razi: Ahkāmu-l-Kur'an, Daru-l-kutubi-1-'ilmijje, Bejrut, 1994.

4. Džurdžani: El-Išārāt ve-t-tenbihāt fi 'ilmi-l-belāga, priredio Abdulkadir Husejn, Daru-n-nehda, Egipat, bez godine izdanja.

5. Ebu Hajjan el-Endelusi: El-Bahru-l-muhīt, Daru-l-fikr, Bejrut, 1977.

6. Halilović, Safvet: Ebu Bekr er-Razi el-Džessas ve menhedžuhu fi-t-tefsir, Daru-sselam, Kairo, prvo izdanje 2001., drugo izdanje 2008.

7. Halilović, Safvet: Metodologija tumačenja Kur'ana u hanefijskome mezhebu, studija na primjeru El-Džessasovog tefsira Ahkamu-l-Kur'an (Propisi Kur'ana), Fakultet islamskih nauka u Sarajevu i El-Kalem, Sarajevo, 2004.

8. Halilović, Safvet: Osnovi tefsira, Islamski pedagoški fakultet, Zenica, 2005.

9. Hejsemi: Medžme'u-z-zevāid, Mektebetu-1-Kuds, Kairo, 1934.

10. Jusuf el-Karadavi: Keyfe nete'āmel me'a-l-Kur'āni-l-'azīm, Daru-š-šuruk, Kairo, 1999.

11. Kattan, Menna': Mebāhis fi 'ulümi-l-Kur'ān, Mektebetu Vehbe, Kairo, 1990.

12. Korkut Besim: Prevod značenja Kur'ana, Sarajevo, 1978.

13. Kurtubi: Tefsìru-l-Kurtubi (poznat i kao El-Džāmi'u li ahkāmi-l-Kur'ān), Daru-šša'b, Kairo, 1952.

14. Muftić Teufik: Gramatika arapskoga jezika, Sarajevo, 1998.

15. Mustafa Ibrahim el-Mišni: Medresetu-t-tefsīr fi-l-Endelus, Muessesetu-r-risale, Bejrut, 1986.

16. Rešid Rida: Tefsiru-l-Menār, četvrto izdanje, Kairo, 1960. 
17. Sujuti: Ed-Durru-l-mensūr, Daru-l-kutubi-l-ilmijje, Bejrut, 1990.

18. Sujuti: El-Itkān fi 'ulümi-l-Kur'ān, Daru-l-fikr, Bejrut, 1978.

19. Zehebi, Muhammed Husejn: Et-Tefsir we-l-mufessirün, Daru-l-kutubi-l-hadise, Kairo, 1976.

20. Zerkeši: El-Burhān fi 'ulūmi-l-Kur'ān, Daru-1-ma'rife, Bejrut, 1971. 
Safvet Halilovic, $\mathrm{Ph} \mathrm{D}$

\section{ARABIC LINGUISTICS AND TAFSEER}

\section{SUMMARY}

Good knowledge of Arabic language and Arabic linguistics is the foundation of accurate and valid interpretation of the Qur'an Tafseer. Without knowledge of Arabic language and its disciplines it is not possible to properly understand the Qur'an. Therefore, scholars emphasize that dealing with the interpretation of the Holy Qur'an is not permissible without the prior knowledge of Arabic linguistics. Otherwise, the door for the wrong interpretation of the Qur'an, which is the main source of Islam, would be wide open.

Knowledge of Arabic language and disciplines of Arabic linguistic science are one of the basic prerequisites for engaging in the science of Tafseer. It is not allowed, nor is it possible that a commentator (mufessir) of the Qur'an does not know Arabic - the language in which the Qur'an was revealed. This includes knowledge of disciplines covered by the Arabic linguistic sciences, such as etymology, syntax, grammar, poetics, stylistics, etc. Engaging in the interpretation of the Holy Qur'an without fulfilling these requirements is very harmful because it leads to erroneous and distorted interpretation of the Book of Allah, and this means the modification of Allah's messages revealed in the Qur'an. This can result in a heresy, infidelity and apostasy from Islam.

This paper discusses the importance of Arabic linguistics in the correct interpretation of the Holy Qur'an. Numerous examples have been listed which prove the previous statement. They are taken from the classic Tafseer works, especially from the work Ahkam-ul-Quran (The Regulations of the Qur'an), whose author is a noted scholar of the Hanafi legal school Abu Bakr Ar-Razi, Al-Ghassas.

Keywords: Tafseer, Arabic linguistic science, linguistics, stylistics, metaphor, the true meaning, allusion, conciseness, AlGhassas, Ahkam-ul-Qur'an. 
الأستاذ الدكتور صفوت خليلوفيتش

\section{علم اللغة العربية والتفسير}

\section{خلاصة البحث}

إن المعرفة الجيدة للغة العربية وعلم اللغة العربية هي أساس التفسير، وأساس

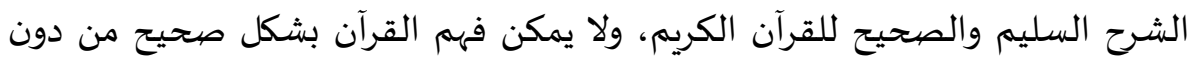

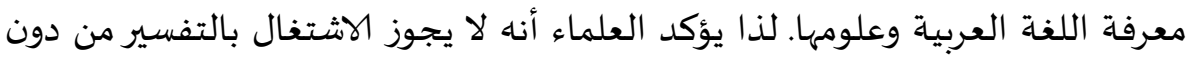

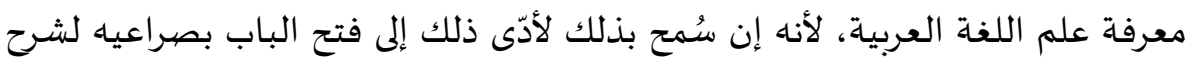
خاطئ للقرآن الكريم الذي يعتبر المصدر الرئيسي للإسلام.

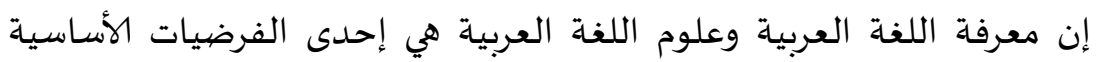

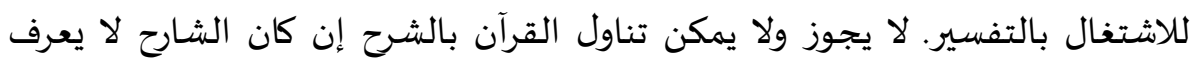

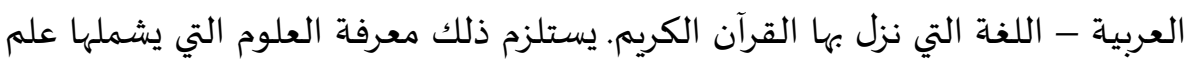
اللغة العربية مثل علم الاشتقاق، علم النحو، علم القواعد، علم الشعر، علم البلاغة، الثرانه

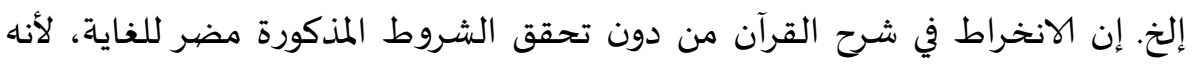

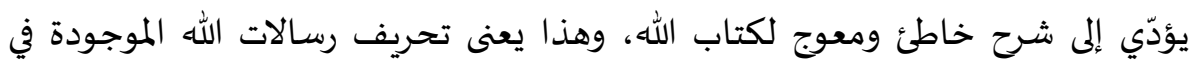
القرآن، وقد يؤدي ذلك إلى الكفروالى شعالى ومدة عن الإسلام.

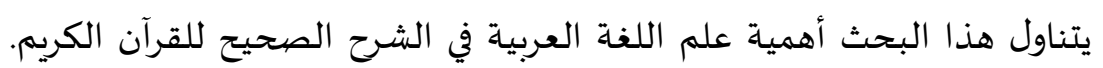

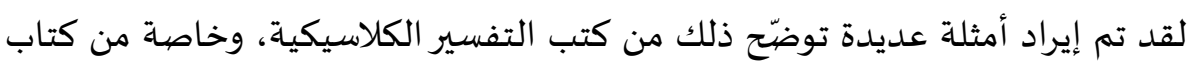

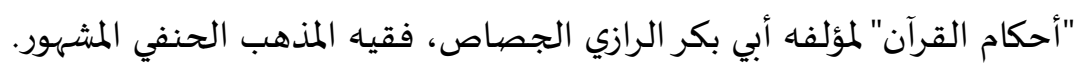

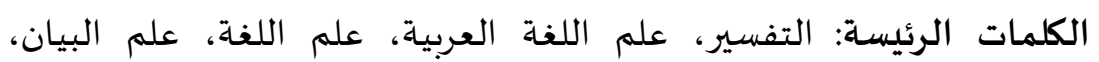

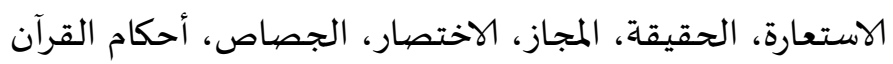

